\title{
The development of the KZR INiG System - european certification scheme
}

\begin{abstract}
In the article key aspects concerning the certification of sustainable production of biofuels, with particular focus on the KZR INiG System were discussed. Firstly, the main aspects of energy production, especially in the context of the impact on the natural environment and the necessity of its verification were presented. In the second part of the article the main steps of development of the KZR INiG System - the Polish certification scheme recognized by the European Commission were presented. Special emphasis was put on the features which are characteristic for the KZR INiG System.
\end{abstract}

Key words: biofuel; sustainability, certification scheme.

\section{Rozwój Systemu KZR INiG - europejskiego systemu certyfikacji}

\begin{abstract}
W artykule przedstawiono kluczowe aspekty w zakresie zrównoważonej produkcji biopaliw, ze szczególnym uwzględnieniem Systemu KZR INiG. W pierwszej kolejności przedstawiono główne zagadnienia związane z produkcją energii, szczególnie pod kątem wpływu na środowisko naturalne i jego weryfikacji. W drugiej części artykułu przedstawiono główne etapy rozwoju systemu KZR INiG - polskiego systemu certyfikacji, uznanego przez Komisje Europejską. Szczególny nacisk został położony na cechy charakterystyczne dla Systemu KZR INiG.
\end{abstract}

Słowa kluczowe: biopaliwa, zrównoważony rozwój, system certyfikacji

\section{Introduction}

Highly developed societies pay great attention to "greenness" of products used in all areas of human life. Since natural products are considered environmentally friendly, the development of production of goods of fully or partially biological origin can be observed. However, using bio-originating feedstock for goods production, sometimes may not mean environmental benefits. The awareness of this fact is widespread among policymakers, scientists and regular people. As a consequence, ideas of reducing carbon footprint also, in the whole chemistry industry are being developed [5]. There are similar tendencies on the fuel and oil derivative market. On the other hand, especially among developed countries, one can observe continuously, an increas in demand for energy sources, especially engine fuels. Conventional engine fuels still remain the main car drive source. Therefore, a challenge arises: combination of satisfying the demand for engine fuels and caring for the natural environment. In the area of power engineering activities, there is one more case of great significance - the issue of power security, i.e. ensuring independent energy sources. All these aspects indicate, despite the occurring negative opinions, advisability of the use of renewable energy sources, as is evident in the European legislature. The main legislative act in this area is directive $2009 / 28 / \mathrm{EC}$, referred to as the RED directive [11]. It assumes systematic increase of the share of energy from renewable sources by 2020, including by $10 \%$ in transport. Each member state adopted its general goals within the scope of share of energy from renewable sources in the final gross energy consumption in 2020. Sweden intends to achieve the greatest share of energy from renewable sources in $2020-49 \%$, whereas Malta the lowest - 10\%.

Currently, it seems that there is also no future for power engineering of engine fuels without renewable energy sources. It is, thus, important to direct this branch of economy in such a manner, so that no damage is caused to the natural 
environment. So, to be sure of that, there is a necessity of having clearly set requirements, criteria and also tools to verify whether these criteria are met. An in depth discussion concerning a systematic approach to evaluating sustainability of biofuel systems was carried out in [6]. Authors pointed out, that assessment of the system should also take into ac- count economical and social aspects. This problem was also perceived by CEN (European Committee for Standardization www.cen.eu), and in order to provide harmonized tools to define an assessment of sustainability, a set of standards in this aspect was published. The discussion concerning this group of standards was carried out in [1].

\section{The need of confirmation of greenness of biofuels}

Due to such an orientation of the European Union policy, European refineries are facing the challenge of recognizing renewable energy sources as raw materials for fuel production. Currently, this task is implemented mainly by blending conventional engine fuels with biofuels. Setting high goals for a share of energy from renewable sources in fuels, implemented mostly by the application of biofuels, has to have an impact on the natural environment, as the natural environment is the source of obtaining it. Bearing the potential hazard in mind, the European Community has introduced requirements that must be met by the biofuels to be suitable for use for their intended purposes. These requirements - sustainability criteria - are described in directive 2009/28/EC called the RED (Renewable Energy Directive). It is obvious that demonstrating of fulfillment of the sustainability criteria will cause additional cost for biofuel producers and all entities in the supply chain. But, as it was discussed in [7] this cost should be balanced by higher prices of the sold product. What more, popularization of certification makes certification cheaper.

According to the RED, sustainability criteria can be divided into two areas of issues. One of them is the capability of biofuel to reduce emission of greenhouse gases in the life cycle in relation to their fossil comparator. Whereas, the other is connected with the protection of areas where plants for production of biofuels are cultivated.

The provisions of the RED mean that, in practice, only those biofuels which prove the capability of reducing significantly the emission of greenhouse gasses in their life cycle and prove that used raw materials do not cause damage to the natural environment during the plant cultivation can be applied. Directive 2009/28/EC, in addition to the set of requirements, has also imposed on economic entities the obligation to submit relevant information and conduct independent audits related to the information. Therefore certification of biofuels is necessary against conformity with the sustainable development criteria according to the RED requirements. This problem was deeply discussed in [9].

When establishing the legal requirements, it was necessary to indicate the tools needed for confirmation of their fulfillment. In this case, the obligation of certification of biofuels against conformity with the sustainability criteria has become such a tool, implemented, among other things, by means of the voluntary schemes recognized by the European Commission (EC) by way of decision. Voluntary schemes verify compliance with the EU's biofuels sustainability criteria. They ensure by way of checks that biofuel production did not take place on land with high biodiversity, that land with high carbon stock was not converted for biofuel production, and that the production of biofuels leads to a sufficient enough level of greenhouse gas emissions savings. Several schemes also take into account additional sustainability aspects such as soil, water, air protection and social criteria [4]. They are run mostly by private organizations, and what is important, is they differ in the scope of certification. A review of recognized voluntary schemes was performed in [8]. One of the recognized schemes is the KZR INiG System - the Polish certification scheme of sustainable production of the biofuel.

\section{The KZR INiG System}

On 3 June 2014 the European Commission issued a decision recognizing the "KZR INiG System" for demonstrating compliance with the sustainability criteria under Directives 98/70/EC and 2009/28/EC of the European Parliament and of the Council [3]. This was a very dynamic period - in its first year the system developed greatly.

The only Polish certification system for sustainable production of biofuels is the KZR INiG System. Having operated in the biofuel area for many years, the Oil and Gas Institute
- National Research Institute commenced works connected with the preparation of a certification system subject to recognition by the European Commission.

The system was developed on the basis of requirements of the RED directive [11], implementation of the KZR INiG System is to provide economic operators, operating in the supply chain of biofuels and bioliquids with the possibility to prove, that they meet sustainability criteria, according to the requirements of the RED. Each voluntary system recognized by the 
European Commission has a specified scope of certification. This refers both to the territory in which the agricultural raw materials are cultivated or where the biofuels are produced, as well as to the production route, i.e. determination of raw materials for biofuel production and technology. The assessment of the KZR INiG System covers, in terms of compliance with the sustainable development criteria, biomass cultivated and collected in the territory of the European Union, wastes and residues collected in the territory of the EU as well as raw materials, biofuels and bioliquids produced in the territory of the European Union. The assessment covers the entire life cycle of biofuels, bioliquids, commencing from the stage of raw material cultivation or waste collection point, to the final stage of consumption of biofuels and bioliquids, formation of wastes and residues, taking into account all intermediate stages (buying, trading and processing of the biomass). Therefore, the KZR INiG System does not limit the range of biofuels admitted for certification (also biofuels not specified in the RED directive can be certified, e.g. hydrocarbon bio-components or other - of advanced generations), and its only limitation is in regards to the territory of cultivation or production. It is worth paying attention to the fact, that the KZR INiG system also has a clearly set procedure to assess biofuels received in a co-processing process (processing with fossil fuel). The procedure describes the methodology of calculation of biomass fraction and $\mathrm{GHG}$ emission.

The system's requirement are described in ten documents, all published on the scheme's website [2] in the download section. The first document contains general rules, overall descriptions of system participants, ownership and organizational matters. For convenience all definitions are gathered in document number 2. Document no 3 refers to the national legislation. The next three documents are devoted to land requirements. Rules concerning the mass balance system to be implemented in a company's activity are presented in document number 7 . Document number 8 contains the methodology of calculation of GHG emission in the biofuel life cycle. The last two documents describe requirements for certification bodies.

\section{KZR INiG history in brief}

The first works on preparation of the system were commenced already in 2010. The most essential matter was the decision regarding the certification scope. The territorial limitation to the area of the European Union allows to use the already existing systems of supervision and control (e.g. cross compliance) and thus, for limitation of requirements. Whereas, it was decided that the scope of certification will cover the entire supply chain, starting from the agricultural producer. This allows all entrepreneurs involved in the biofuels production or biomass trading to obtain the KZR INiG System certificate - in other words, the designed system is available for anybody who intends to possess a certificate. The scheme's requirements were presented to the European Commission in July 2012 for assessment. From December 2012 to October 2013 the assessment process of correctness of requirements of compliance with the RED was conducted. After substantial assessment was finished, the comitology process began. When consultation among Member States was finished, on June 2014, the decision of recognition was issued.

However, for the system to actually function on the market, it was also necessary to conduct a series of activities, especially the certification bodies recognition process. A certification body, in order to be able to conduct audits and issue certificates of compliance with the KZR INiG System, has to meet the requirements defined by the scheme. The recognition process includes on site audit (in the certification body's headquarters) and witness audit.
The first company to sign a contract regarding cooperation within the scope of the KZR INiG System was DEKRA Certification Sp. z o.o. However, even the best company is worthless if it has no specialists in the given discipline. Therefore, in that period the most important issue for the KZR INiG System was to conduct a cycle of trainings for auditors to conduct audits of compliance with the KZR INiG System requirements.

29 July 2014 was another important date for the System, as it was on that day that the decision on recognition of the first certification body was issued - it was the certification body, DEKRA Certification Sp. z o.o.

Shortly after the recognition of Dekra, further certification bodies began cooperation with the KZR INiG System. By the end of October 2014, they were four: Dekra, SGS, Bureau Veritas and TÜV Rheinland.

The first KZR INiG System certificate was issued on 19 September 2014, issued by Bureau Veritas with the number $\mathrm{BVC} / \mathrm{KZR} / 001 / 14$. The holder of this certificate was the Agricultural Producer Group „JA-ROL” Sp. z o.o.

The system was becoming increasingly popular; by the end of October 2014, 14 certificates had already been issued.

The entrepreneurs operating on the German market, within the scope of German law, purchasing biofuels, register their transactions in Nabisy - a data base created for this purpose and kept by Bundesanstalt für Landwirtschaft und Ernährung (BLE) - Federal Agriculture and Food Agency. In order for the entrepreneurs certified within the scope of the KZR INiG 

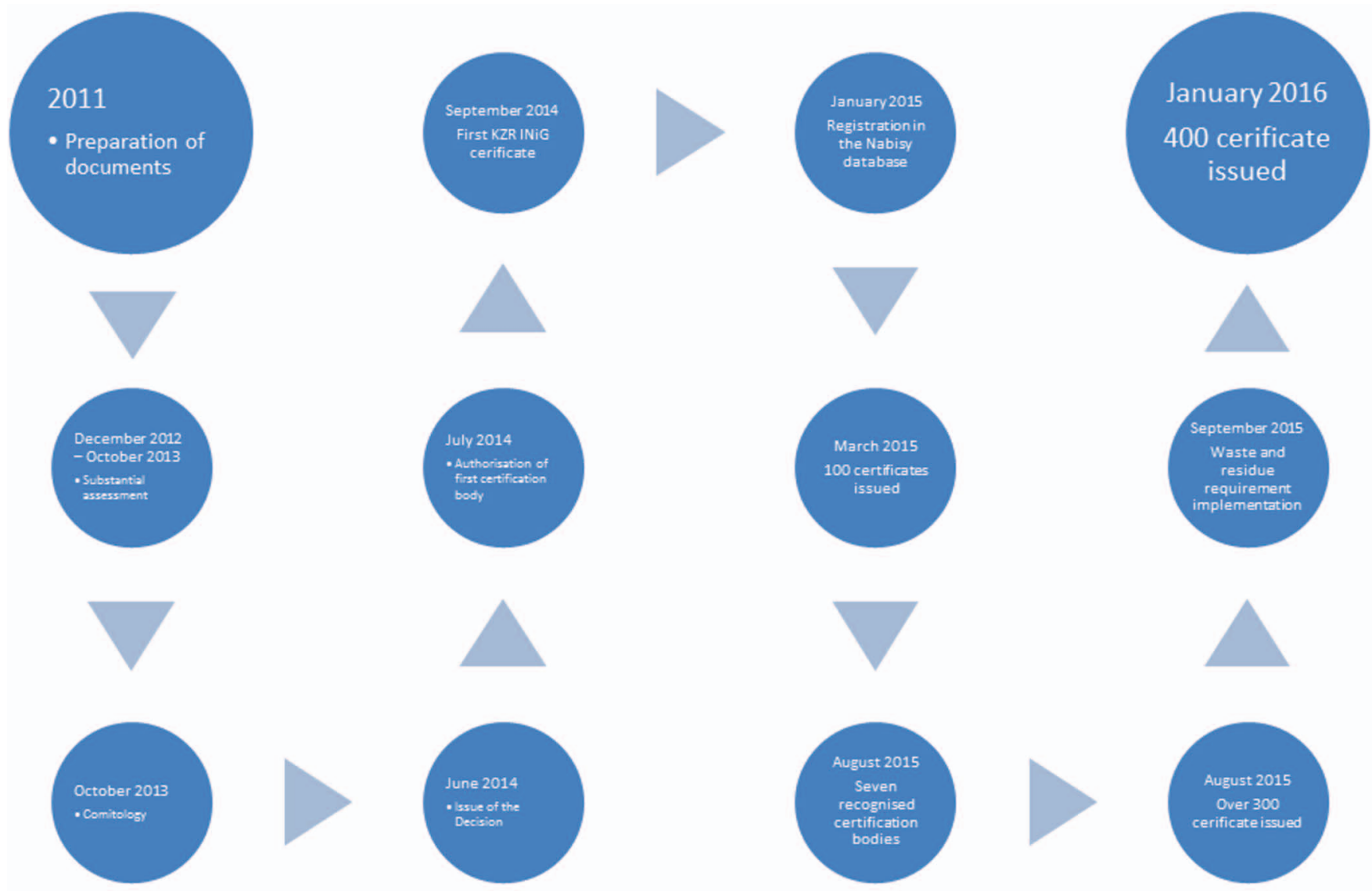

Fig. 1. The KZR INiG System Calendar

Sytem to be able to conclude such transactions, it was necessary to register the KZR INiG System. The system received no. EU-BM-22 - the business entities certified by KZR INiG System register themselves in the Nabisy data base by means of the System which allows them to conclude transactions with our western neighbours.

Interest in the KZR INiG System is continuously increasing. Another, one hundred participants were registered by the end of January 2015, and on 19 March 2015 Bureau Veritas issued its one hundredth certificate awarded to GRUPA LOTOS S.A. In May there were already 200 contracts concluded with entrepreneurs and in July 2015 - over 300. On the exact date of the first anniversary of the decision of recognition of the KZR INiG System, another certification body was added: Noble Cert Sp. z o.o. On August 2015 there were seven recognized certification bodies and more than 300 certificates issued.

Current European policies insist on the development of non-food biofuels. Having in mind the fact that the majority of advanced biofuel technology is still in their pilot stage and the easiest way to produce advanced biofuel is by using waste as a feedstock, one can say that the verification of biofuels originating from wastes has become more and more important. The KZR INiG System implemented requirements concerning auditing of wastes and residues. The rules are coherent with the European Commission recommendation, and have been assessed by the EC.

In the mean time, the European Commission has issued COMMISSION REGULATION (EU) No 1307/2014 of 8 December 2014 on defining the criteria and geographic ranges of highly biodiverse grassland for the purposes of Article $7 \mathrm{~b}(3)$ (c) of Directive 98/70/EC of the European Parliament and of the Council relating to the quality of petrol and diesel fuels and Article 17(3)(c) of Directive 2009/28/EC of the European Parliament and of the Council on the promotion of the use of energy from renewable sources [10]. Definitions set in this Regulation were implemented into the KZR INiG System

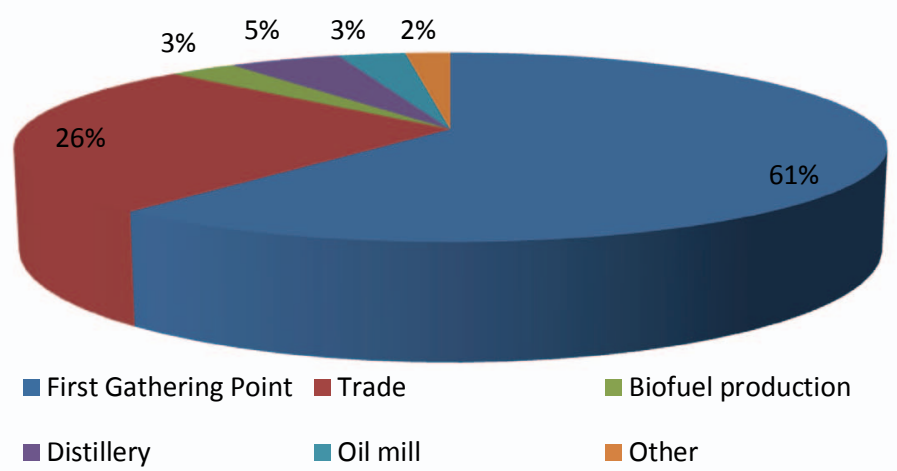

Fig. 2. The share of particular group in the KZR INiG 
requirements, while using highly biodiversed grassland still remains forbidden.

Short summary of the KZR INiG System history is presented on the Figure 1.

The KZR INiG System covers the whole supply chain of biofuels and as a consequence of this scope, is drawn the system participants profile. The share of each group is presented on the diagram below.

The greatest share among the entities participating in the System corresponds to the first gathering points (FGP) and companies involved in trade in biomass. Another important group are: distilleries, FAME producers and oil mills.

\section{What is characteristic of the KZR INiG?}

The certification system is a set of requirements that must be met in the biofuel supply chain so that the final product can demonstrate meeting the sustainable development criteria.

The requirements of the System are compliant with the requirements of the RED, but, first and foremost, they make a number of issues more precise, for example the method of verification of lands on which the raw materials for biofuel production were cultivated, the method of keeping the mass balance or, what is also very important, the methods for calculation of greenhouse gas emission in the service life. Although all voluntary systems are based on the same requirements set in the RED, the specification makes them differ in practice.

The characteristic feature of the KZR INiG System, is the fact that the entities implementing requirements, are recommended to adapt the systems already existing in the company in such a manner, so that they meet the RED directive requirements. The idea of the system is to reduce the excessive administrative load by means of foe example reducing the number of obligatory forms (it is possible to use a different template if all information can fit).

Recently, the procedures for entrepreneurs and audit procedures for the certification body within the scope of waste and residue collection have been made more precise. What is important, these procedures were subject to assessment by the European Union and were approved. The definitions regarding high biodiversity terrains were also revised.
Moreover, the KZR INiG System defines rules for mass balance and GHG emission calculation for biofuels obtained in a co-processing process.

The approach to nonconformities is also specific for the scheme. The KZR INiG System identifies two types of them: minor and major.

Minor nonconformities are those whose causes are detected and can be eliminated within 30 days. The certificate can be issued upon approval of the performed correction by the leading auditor and upon undertaking of corrective actions. In this case, it is recommended to conduct the audit under supervision not later than within six months after completion of the certification audit. If improper correction (or its lack) can potentially result in occurrence of a major nonconformity, the audit under the supervision is obligatory. In case of a singular minor nonconformity, when the proof of correction can be sent to the auditor by means of traditional or electronic mail (e-mail), the decision on the need for audit under supervision belongs to the leading auditor.

Major nonconformities include discrepancies whose causes were not detected or which cannot be eliminated within 30 days. In such a situation, the certificate is not issued or the current certificate is suspended. In case of major nonconformities, the certification unit immediately informs the KZR INiG System administrator, also on the undertaken corrective actions.

The cost of participating in the KZR INiG System is relatively low.

\section{Summary}

In the nearest future, the share of energy from renewable sources will systematically increase, causing an increase in demand for biofuel in the engine fuel area. However, this direction can result in damage to the natural environment, therefore sustainability criteria were introduced for biofuels. According to the current law and current directions the requirement to use biofuels possessing the sustainability certificate concerns all entities dealing with biofuel. Therefore mostly engine fuel suppliers were obliged by the directive to use only biofuel meeting the sustainability criteria which must be confirmed with a proper certificate. A good solution is to obtain the certificate of the KZR INiG System - the only Polish system recognized by the European Commission which allows to conclude transactions in the European Union.

Please cite as: Nafta-Gaz 2016, nr 5, s. 370-375, DOI: 10.18668/NG.2016.05.09

Article contributed to the Editor 14.11.2016. Approved for publication 3.03.2016. 


\section{Literature}

[1] Błaszkiewicz Z.: Normalizacyjne aspekty kryteriów zrównoważonego rozwoju biopaliw - normy EN 16214. Nafta-Gaz 2014, nr 8, s. 541-547.

[2] Certifikcation system of sustainable biofuels and bioliquids production INiG - PIB; www.kzr.inig.eu (access: December 2015).

[3] EUR-Lex: Access to European Union law; http://eur-lex. europa.eu/legal-content/EN/TXT/?qid=1404934125808\&u ri=CELEX:32014D0325 (access: December 2015).

[4] European Commission; https://ec.europa.eu/energy/en/topics/renewable-energy/biofuels/voluntary-schemes (access: December 2015).

[5] Kircher M.: Sustainability of biofuels and renewable chemicals production from biomass. Current opinion in Chemical Biology 2015, vol. 29, s. 26-31.

[6] Mangoyana R. B., Smith T. F., Simpson R.: A systems approach to evaluating sustainability of biofuel systems. Renewable and Sustainable Energy Reviews 2013, vol. 25, s. 371-380.

[7] Pacinia H., Assunçãob L., van Damc J., Toneto Jr. R.: The price for biofuels sustainability. Energy Policy 2013, vol. 59, s. 898-903.

[8] Rogowska D.: Przeglad dobrowolnych systemów certyfikacji biopaliw na zgodność z kryteriami zrównoważonego rozwoju. Nafta-Gaz 2014, nr 4, s. 256-261.

[9] Rogowska D., Majoch A.: A new approach to biofuels - certification of sustainable development according to the RED Directive. Nafta-Gaz 2013, nr 11, s. 843-850.

\section{Legal acts and normative}

[10] COMMISSION REGULATION (EU) No 1307/2014 of 8 December 2014 on defining the criteria and geographic ranges of highly biodiverse grassland for the purposes of Article $7 b(3)$ (c) of Directive 98/70/EC of the European Parliament and of the Council relating to the quality of petrol and diesel fuels and Article 17(3)(c) of Directive 2009/28/EC of the European Parliament and of the Council on the promotion of the use of energy from renewable sources; http://eur-lex.europa.eu/ legal-content/EN/TXT/?uri=CELEX:32014R1307 (access: December 2015).

[11] Directive 2009/28/EC of the European Parliament and of the Council of 23 April 2009 on the promotion of the use of energy from renewable sources and amending and subsequently repealing Directives 2001/77/EC and 2003/30/EC (OJ L 140, 5.6.2009, p. 16).

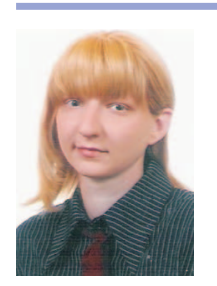

Delfina ROGOWSKA, M.Sc. Eng.

Senior Research and Technical Specialist, Deputy head of the Department of Fuel and Catalytic Processes.

Oil and Gas Institute - National Research Institute 25 A Lubicz St., 31-503 Cracow

E-mail: delfina.rogowska@inig.pl

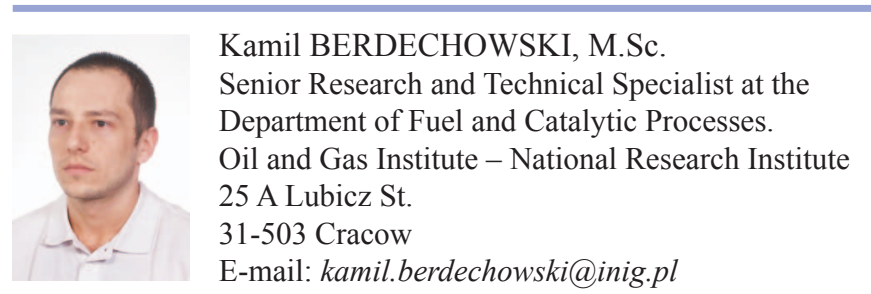

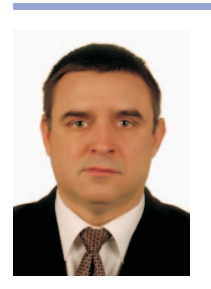

Tomasz ŁACZEK, M.Sc. Eng.

Senior Research and Technical Specialist at the Department of Fuel and Catalytic Processes. Oil and Gas Institute - National Research Institute 25 A Lubicz St.

31-503 Cracow

E-mail: tomasz.laczek@inig.pl

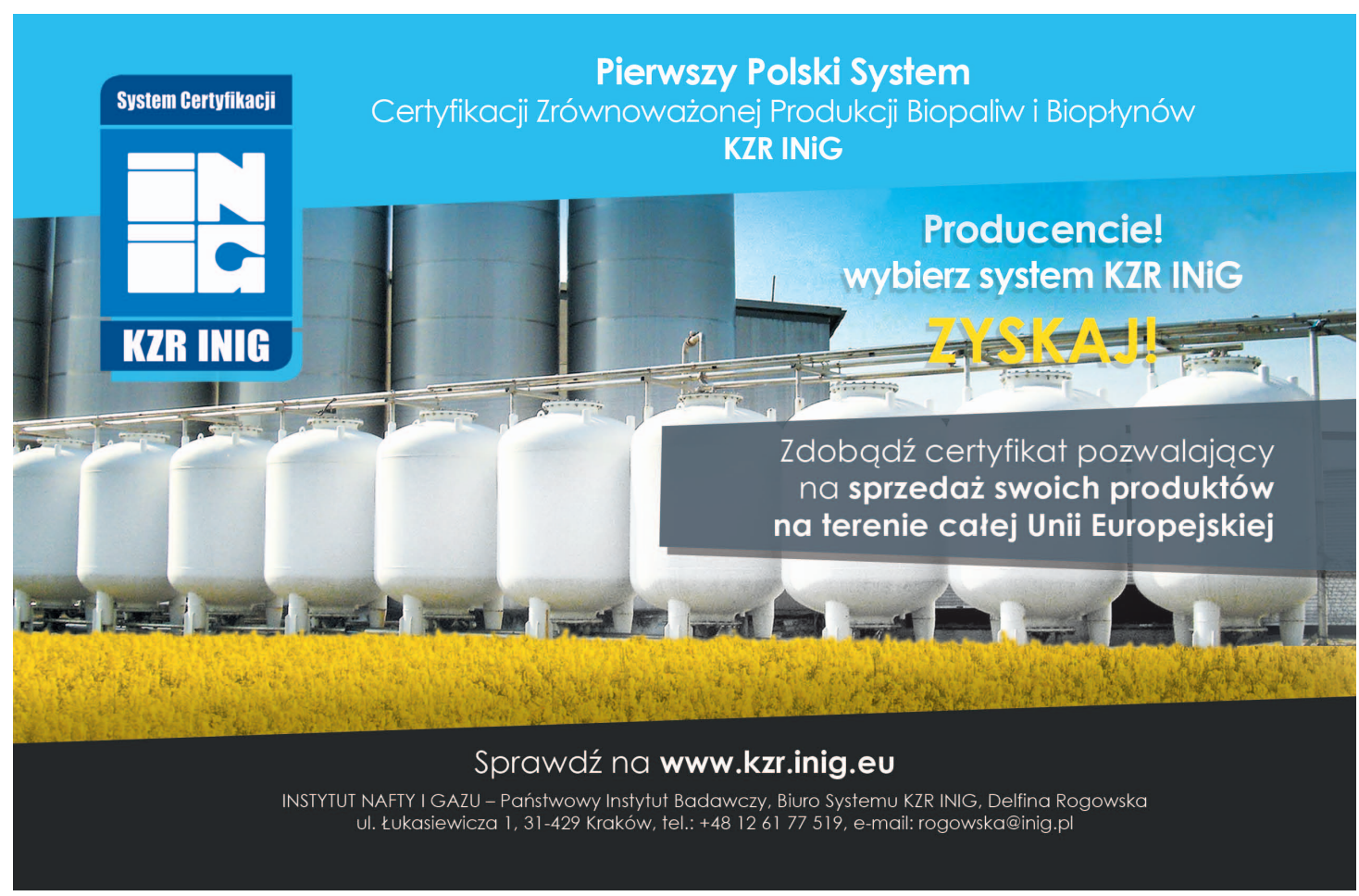

